\title{
The Green Electricity: The Potential of Using Solar Pv Panel for The Royal Malaysian Police (RMP) Building
}

\author{
Md Hafiz Md Yasin',a and Nur Azfahani Ahmad² \\ ${ }^{1}$ Master of Green Architecture, Faculty of Architecture, Planning and Surveying, UiTM Perak, 32610, Perak, Malaysia. \\ ${ }^{2}$ Department of Building Surveying, Faculty of Architecture, Planning and Surveying, UiTM Perak, 32610, Perak, Malaysia
}

\begin{abstract}
As the year 2020 approaches, Malaysia aims to be self-sufficient and independence in finding resources to fuel its development, especially in energy sector. To achieve this aims, Malaysia need to strengthen its energy sustainability aspect and have a clear foresight in handling energy security issue. In coming decades, energy crisis due the existence of the significant energy threat may cause power interruptions and lead to many interrelated problems, especially safety and security issues. Issues such as unstable political and economic situation in Middle East country, Spratly issue, South China Sea territorial issue, war and terrorist may lead to unstable safety and security environment for Malaysia. The most significant organization to keep the safety and security of Malaysia is The Royal Malaysian Police (RMP). However, at the moment, this organization is fully-reliant on centralized electricity supply that may interrupt due to the future energy threat. Therefore, it is important for this organization to have an independence and self-sufficient electricity supply in order to remain their operation in any circumstances. The solar energy, through Photovoltaic (PV) panel, has been identified as the significant resources to achieve this purposes. With constant solar irradiance, Malaysia has great potential in solar energy harvesting. The energy is clean, environmental-friendly, reliable and readily-accessible throughout the year. This paper will review the potential of green electricity through solar PV in being the power supply for RMP in order to maintain the security and safety of Malaysia
\end{abstract}

\section{Introduction}

Electricity is a common energy and the utmost form of energy which contributed in driving the economies development of all nations in the world (Ali, Daut, \& Taib, 2012). Therefore it is always a challenging to meet all the growing demand on time it is needed. Furthermore, according to Ali et al (2012) this growing demand was accompanied by the growing population. It is also a fundamental too many stakeholders, which comprise policymakers, businesses, industrial sector, transportation sector, construction sector, agricultural sector and larger communities of where their quality of life depend on the uninterrupted of energy supply (Ang, Choong, \& Ng, 2015). It is almost impossible to achieve the sustainable development without sustainable energy supply (Ismail, Ramirez-Iniguez, Asif, Munir, \& Sukki, 2014). This is supported by Selvakkumaran and Limmeechokchai (2013) which strengthened that energy security is an essential factor for countries aiming for sustainable development.

Energy is an indispensable factor to spur the economic growth and create the sustainable development of a country. Whilst, energy security is a situation of an independence supply of energy which able to meet demand at all times when it is needed (Hashim, 2010).
An exploratory study by Hashim (2010) highlighted that Malaysia is facing an incoming issue of oil and gas declining ${ }^{\mathrm{a}}$. Hashim (2010) outlined that Malaysia oil and gas reserves far less compared with Middle East country. In addition, the study by Othman and Jafari, (2012) found out the major reduction of oil reserves from 2001 to 2005. Meanwhile natural gas reported depleted mainly in 2004 and 2005. This scenario shows by Table 1 and Figure 1. This energy crisis occurs due to the significant energy threat that may cause power interruptions and lead to many interrelated problems, especially on the safety and security aspect. Issues such as unstable political and economic situation in Middle East country, Spratly issue, South China Sea territorial issue and war may lead to energy 'gap' (insufficient) scenario (Ahmad, 2011). This will eventually create unstable safety and security environment for Malaysia.

Since the Independence Day in 1957, Malaysia has relies on oil and gas as the main sources of electricity.

\footnotetext{
${ }^{2}$ Malaysia only accounts for only $3 \%$ and $8 \%$ of world discovered oil and gas reserves, respectively; but $30 \%$ and $15 \%$ of consumption Hashim (2010).
}

\footnotetext{
${ }^{\mathrm{a}}$ Corresponding author:hafizyasin@rmp.gov.my
} 
However this non- renewable energy depleted over the time whilst Malaysia moving towards rapid development. Obviously, this development will required substantial energy demand to support the country's needs (F.M Sukki R.R Inigueza, S.H. Abu-Bakar \& S.H. Mohd Yasin B.G. Stewart, 2012). Concerning about the aforementioned issues, in July 2009, Malaysian Prime Minister, Datuk Seri Najib Tun Razak has launched the National Green Technology Policy and followed by the Renewable Energy Act, in 2011, as an effort to resolve the energy security issues (F.M Sukki et al., 2012). Figure 2 shows the effort made by the government in establishing the energy related policies and initiatives from 1971 to 2015.

\section{The Scenario Energy Development In Malaysia}

In Malaysia, the growing population has increased annually by $1.8 \%$ from 27.4 million in year 2007 and is expected to increase to 33.4 million in 2020 (Ali et al., 2012). Furthermore, Ali et al (2012) stated this figure is projected to be increased five times higher in 2030. With the growing population, the total electrical power generated has projected to be increased from 103.2TWh in 2009 to 274TWh in 2030(Ali et al., 2012).

This data has demonstrated a significant understanding that with the increased numbers of people, more energy is needed; therefore more power electricity will need to be generated. This view has been shared by Oh, Lalch and Chua (2014) which highlighted that the increasing trend of power generation is based on the trend of Malaysian oil and gas reserve margin. With the declining of the fossil fuel reserve, there is a possibility that the power generating capacity will be reduced as well. Oh et al (2014) emphasized that this will be a tough job for the Malaysian government to meet the rising demand unless, there are efforts in strengthening its power sector with renewable energy. Figure 3 shows the power development plant for Peninsular Malaysia from 2010 to 2031.

This situation has been driven by the rapid development of industrial and commercial sector. Johari, Hafshar, Ramli, and Hashim (2011) emphasized that industrial and commercial sector was the major energy user in 2009. This is shown in Table 2. However, Ali et al (2012) highlighted that the industrial and residential sector was the main reason towards the increasing trend of power electricity demand. The study by Ahmad (2011) revealed that the rapid development of Malaysia which commencing since 1980s, in conjunction with the construction of spectacular landmarks, such as Petronas Twin Tower, the Kuala Lumpur International Airport (KLIA), the Light Rail Transit (LRT) and the SMART tunnel system have increased the energy demand.

\section{Future Issues Of Energy In Malaysia}

Imbalance supplies between the energy demand and energy reserve will significantly give an impact towards the energy security aspect for Malaysia. Definitely, one of the main impacts is power blackouts (Byrd, 2014).

Ahmad (2011) noted that power blackouts will significantly affect the networking connectivity of various technologies and loss of communication is considered a major issue for Malaysia. Furthermore, Ahmad (2011) also stated that the power blackout lead to massive problem in a community, for instance, delay in food supplies, increased crime rate, health disruption, cancellation of flights and many businesses mess. A loss of electricity not only can affect within domestic sector but also millions of Ringgit Malaysia (RM) in various industries sectors, tourism, transportation, distribution of clean water, security system and banking system. The issues of energy threat also associated with the external factors. Issues such as unstable political and economic situation from world oil major player in Middle East country, Spratly issue, South China Sea territorial issue, war and terrorist may lead to unstable safety and security environment for Malaysia (Ahmad, 2011).

Looking back to the histories of power shortage in Malaysia, several event of power blackouts were recorded (Ahmad, 2011). The national power disruption occurred on $29^{\text {th }}$ September 1992 (2 days), $3^{\text {rd }}$ August 1996 (12 hours), $10^{\text {th }}$ August 1996 (16 hours), $4^{\text {th }}$ September 2003 (5 hours) and $3^{\text {rd }}$ February 2005 (2 hours) where the whole of Peninsular Malaysia including Kuala Lumpur, Selangor, Putrajaya, Johor, Malacca and Negeri Sembilan turn into darkness and have affected many commercial industries in Malaysia (Ahmad, 2011). Almost after 10 years, another massive power disruption occurred in Sarawak, the biggest state in Malaysia. It has been highlighted by Mering (2015), where the case occurred in 23 June 2015 and another conjunction cases, according to Davidson (2015) happened on 5 November 2015. The blackout caused severe traffic jams in the major urban centers of the state and caused huge losses for many businesses. Therefore, it is necessary to consider green electricity as alternative resources for generating electricity in Malaysia

\section{Solar Electricity: The Green Electricity}

The 'Green Electricity' term can be referred as the electricity generated from Renewable Energy (RE) sources, for instance, sun, wind, water, geothermal and biomass waste (Hobman \& Frederiks, 2014). Generally, all the RE sources are non-polluting, inexhaustible and low emission of Carbon Dioxide $\left(\mathrm{CO}_{2}\right)$. Therefore, most researchers consider REs as the vitalalternative energy for the future (Ismail et al., 2014).

Solar energy has been identified as the substantial resources compared to others elements of Renewable Energy (Kadir, Rafeeu, \& Adam, 2010). 
Table 1: Comparison of Oil \& Gas Reserves - Asia-Pacific vs. the Middle-East (Hashim, 2010)

\begin{tabular}{|c|c|c|c|c|}
\hline \multirow[t]{2}{*}{ Oil } & \multicolumn{2}{|l|}{ Reserves } & \multicolumn{2}{|l|}{ Consumption } \\
\hline & billion barrels & $\begin{array}{l}\% \text { of } \\
\text { world }\end{array}$ & $\begin{array}{l}\text { million barrels per } \\
\text { day }\end{array}$ & $\begin{array}{l}\% \text { of } \\
\text { world }\end{array}$ \\
\hline $\begin{array}{l}\text { Asia-Pacific } \\
\text { (Malaysia) }\end{array}$ & $\begin{array}{l}40.8 \\
(5.4)\end{array}$ & $\begin{array}{l}3 \% \\
(0.4 \%)\end{array}$ & $\begin{array}{l}25.4 \\
(0.5)\end{array}$ & $\begin{array}{l}30 \% \\
(0.6 \%)\end{array}$ \\
\hline Middle-East & 755.3 & $61 \%$ & 6.2 & $7 \%$ \\
\hline \multirow[t]{2}{*}{ Gas } & \multicolumn{2}{|l|}{ Reserves } & \multicolumn{2}{|l|}{ Consumption } \\
\hline & trillion cubic $\mathrm{ft}$ & $\begin{array}{l}\% \text { of } \\
\text { world }\end{array}$ & $\begin{array}{l}\text { billion cubic feet } \\
\text { per day }\end{array}$ & $\begin{array}{l}\% \text { of } \\
\text { world }\end{array}$ \\
\hline Asia-Pacific & $\begin{array}{l}511 \\
(87)\end{array}$ & $\begin{array}{l}8 \% \\
(1 \%)\end{array}$ & $\begin{array}{l}43 \\
(2.7)\end{array}$ & $\begin{array}{l}15 \% \\
(1 \%)\end{array}$ \\
\hline Middle-East & 2,585 & $41 \%$ & 29 & $10 \%$ \\
\hline
\end{tabular}

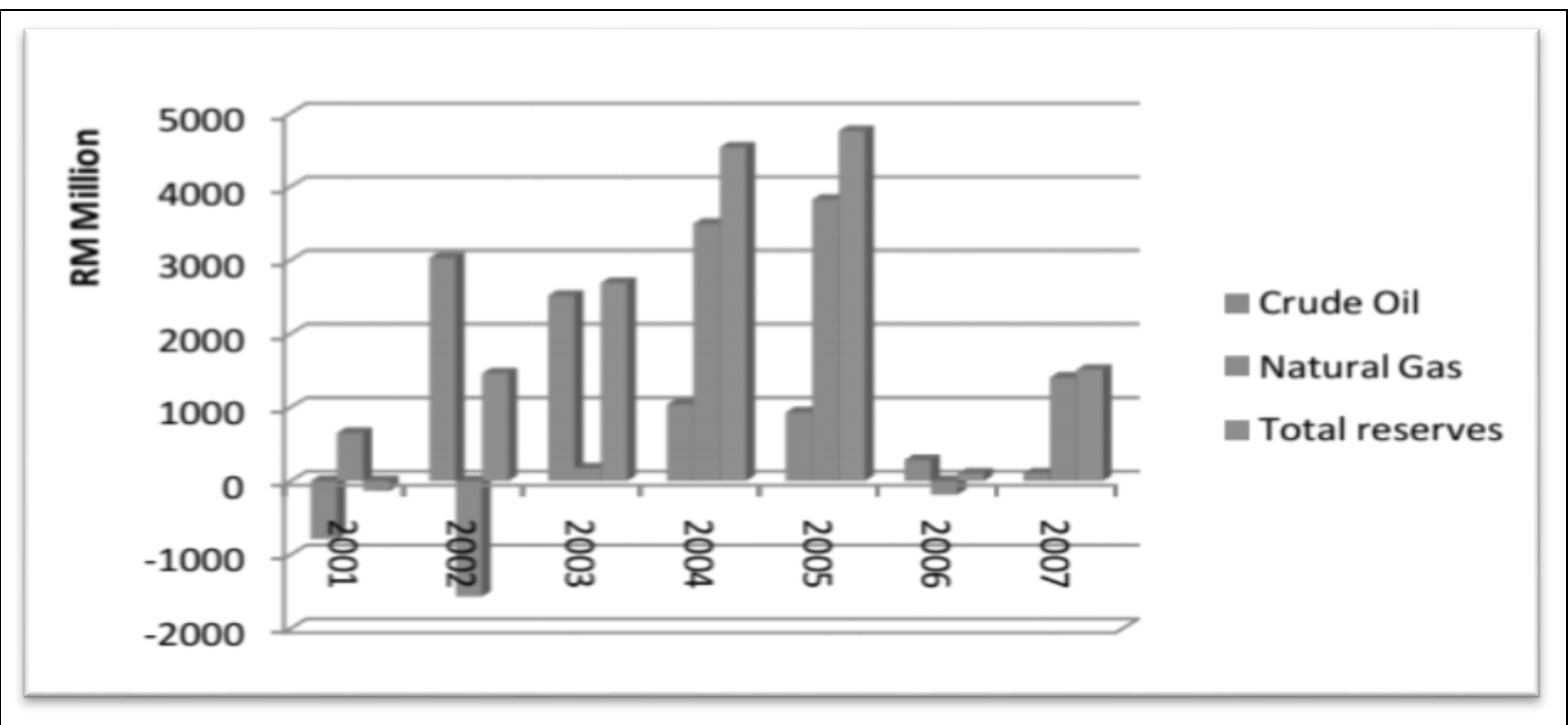

Figure 1: Malaysia natural reserves depletion for crude oil, natural gas and total reserves (Othman \& Jafari, 2012).

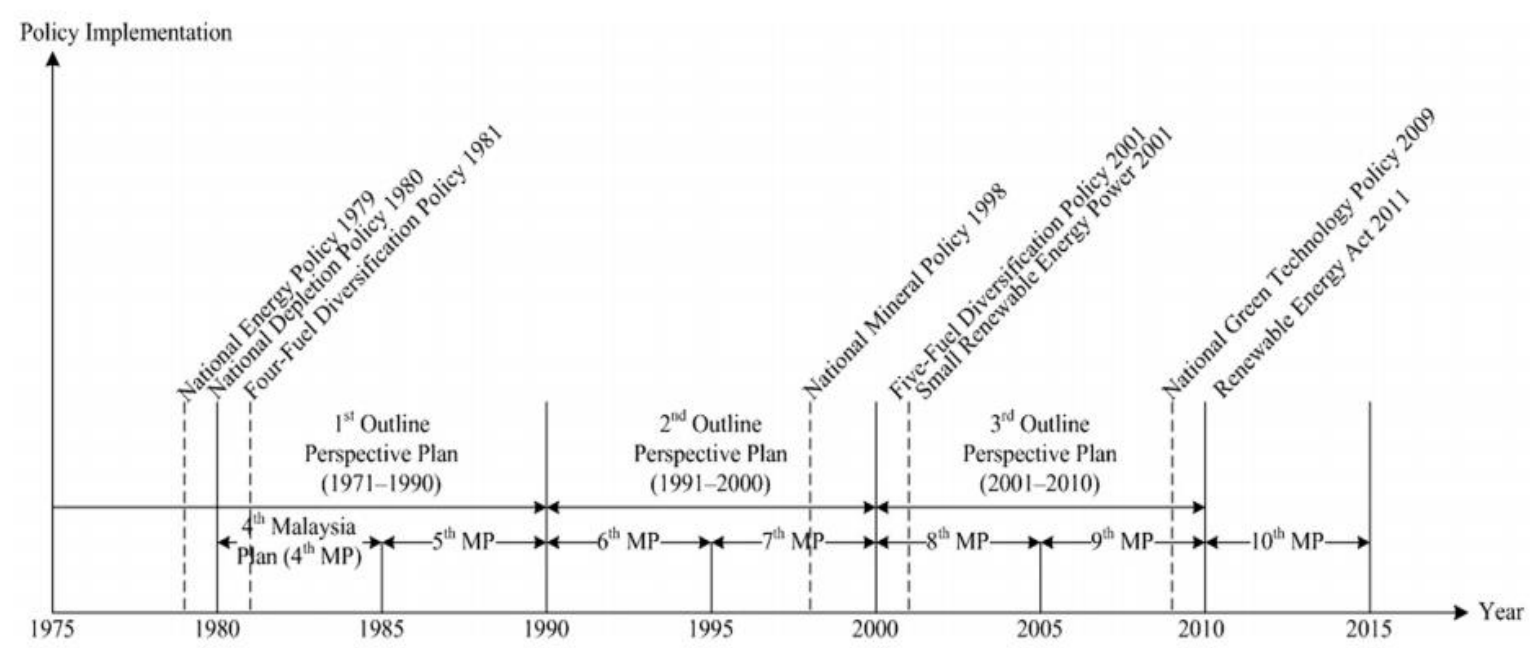

Figure 2: The timeline for energy related policies and initiatives, from 1971 to 2015 (C.S Khor, 2014) 


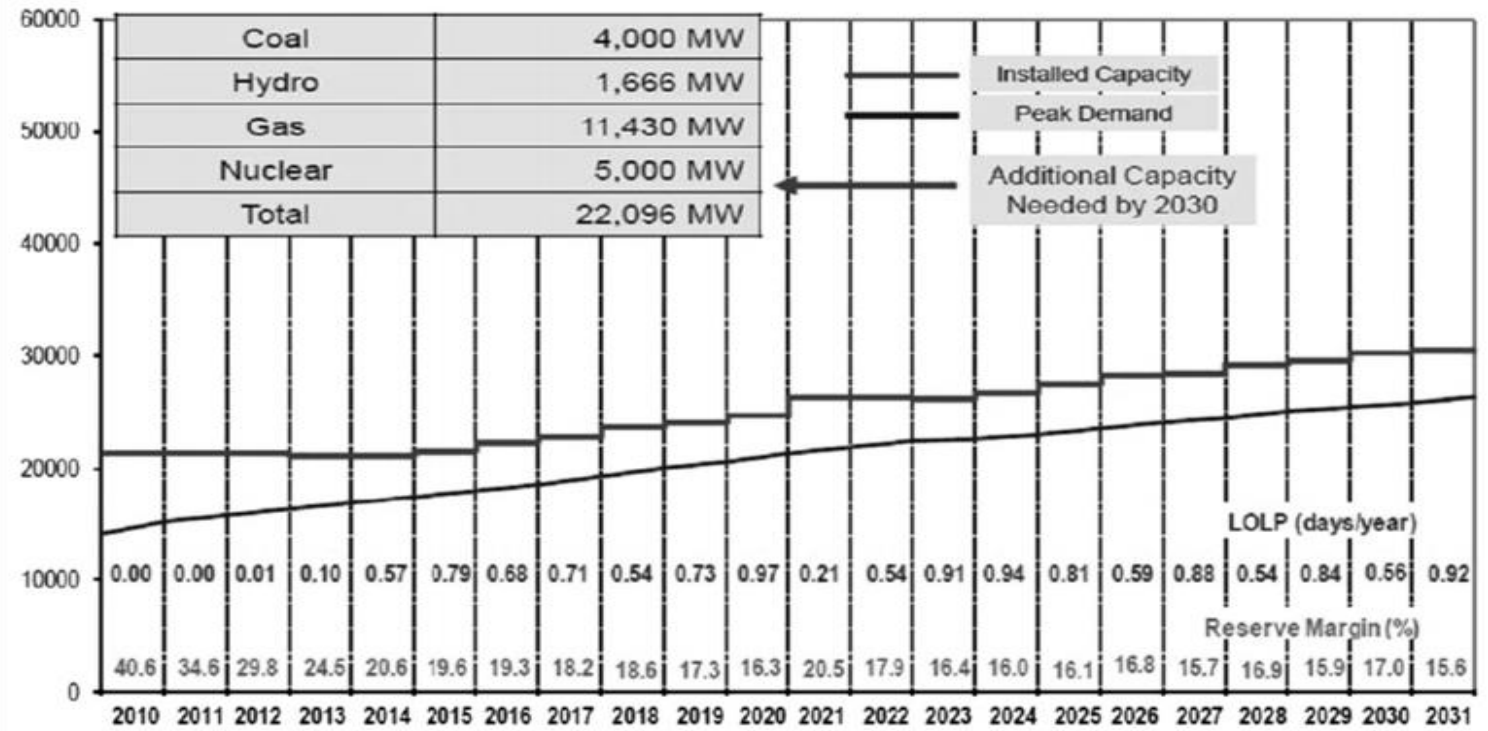

Figure 3: Peninsular of Malaysia power generation plan (from 2010 to 2031) (Oh et al., 2014)

\begin{tabular}{|l|c|c|}
\multicolumn{2}{c}{ Table 2: Energy Usage by Sector 2009 (Johari et al., 2011) } \\
\hline \multicolumn{1}{|c|}{ Sector } & $\begin{array}{c}\text { Sales of Electricity } \\
(\mathrm{GWh})\end{array}$ & Percentage (\%) \\
\hline Industrial & 40,233 & 43.4 \\
\hline Commercial & 31,435 & 33.9 \\
\hline Residential & 19,584 & 21.1 \\
\hline Agriculture & 243 & 0.3 \\
\hline Public Lighting & 1,208 & 1.3 \\
\hline Total & 92,753 & 100 \\
\hline
\end{tabular}

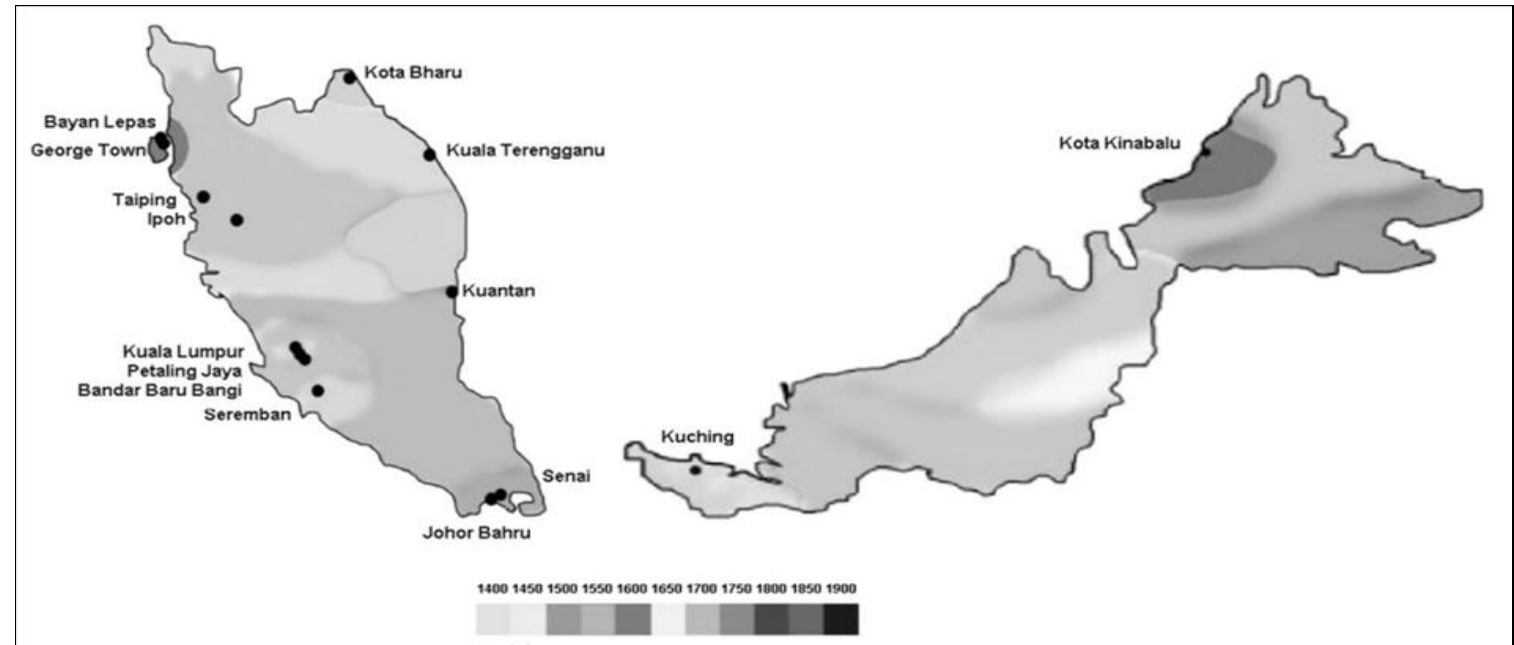

Figure 4: Yearly solar insolation in Malaysia (Adapted from Muhammad-Sukki, Ramirez-Iniguez, Abu-Bakar, McMeekin, \& Stewart, 2011) 


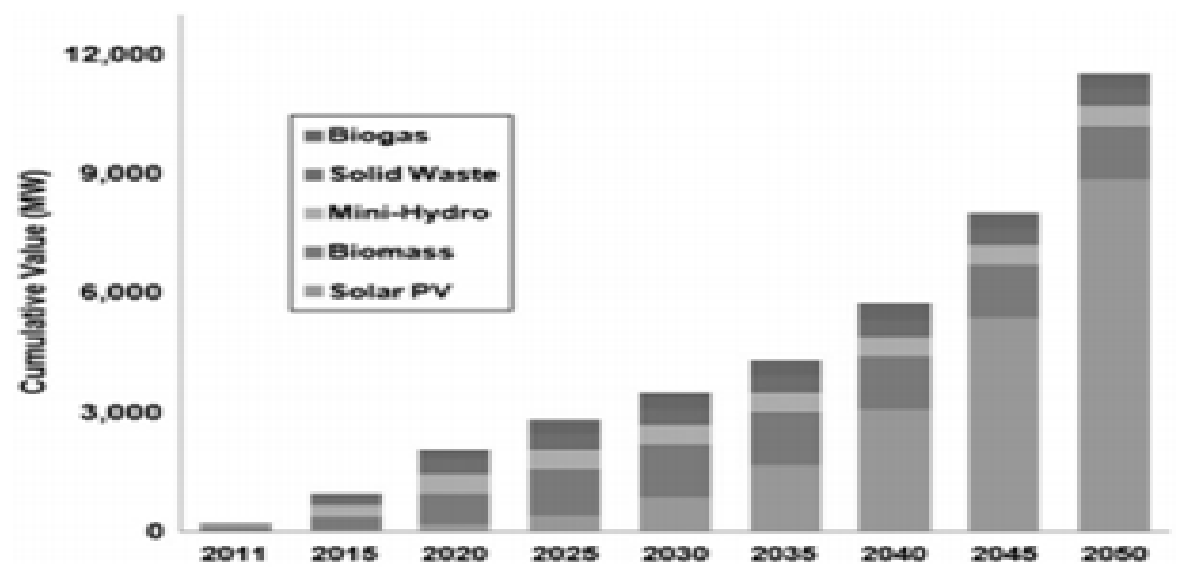

Figure 5: Cumulative value of RE in Malaysia (2011-2050). Adapted from (F.M Sukki et al (2012)

This is supported by Ismail et al (2014) which highlighted that solar energy is one of the most promising and prominent forms of RE. Malaysia has a great potential in harvesting solar energy. With the location situated in the South East Asia region and comprising with the total area of 329,847 $\mathrm{km}^{2}$ (F.M Sukki et al., 2012), Malaysia receives abundant sunshine every year. The daily sunshine irradiance averaging at $1643 \mathrm{kWh} / \mathrm{m}^{2}$ per year (Chua \& Oh, 2011). Ismail et al (2014) stated that Malaysia receives a high amount of solar insolation, ranging from 1400 to $1900 \mathrm{kWh} / \mathrm{m}^{2}$ per year and according to Amin, Lung, \& Sopian (2009), Malaysia experiencing 10 sun hours per day. With that constant solar irradiance, the potential of solar energy that could be harvested until 2030 is up to $6,500 \mathrm{MW}$. Figure 4 show the yearly solar insolation in Malaysia.

Given its potential and supported with the government scheme, such as Feed In Tariff (FiT), the solar PV market penetration in Malaysia is expected to expand in the future (F.M Sukki et al.,(2012). Figure 5 shows the potential of solar energy sector in Malaysia through the cumulative value of RE provided by the Government. The solar PV system itself contains super advantages compared with others technologies. According to Frank Jackson (2007) among the well-known advantages is long life through its life cycle which is 21 to 25 years with low maintenance. In addition, the technology deliver varies efficiency from $7.5 \%$ to 16.9 $\%$ accordingly with the type of cell material. This is supported by Hasimah and M.N.Khalid (2009) that had found out the comparative result for the different technologies of Solar PV system. Meanwhile, research by Amin et al (2009) notified different solar panel will demonstrate the different efficiency under different environment.

\section{The Case Study}

For this research, the Royal Malaysian Police (RMP) organization has been chosen as the case study. It is a known fact that the most significant organization to keep the safety and security of Malaysia is The Royal Malaysian Police (RMP). However, at the moment, this organization is fully-reliant on the centralized electricity supply from the main power utility. It is a major concern that the electricity supply may be interrupted due to the upcoming energy threat. Therefore, it is essential for this organization to have an independence and self-sufficient electricity supply in order to remain their operation in any circumstances. In this millennium era, globalization issue and advance-evolving technology are among the issues that must be control by the Royal Malaysia Police (RMP) in order to ensure the effectiveness of its 
enforcement. A world without borders has been created through this rapid development of technologies which requires the paradigm shift in police enforcement. Therefore, RMP need to be more adaptive to the environment; to be always in "alert" situation and moving along with the latest technology development. They need to be aware on their capability in managing current threat, either from domestic or international level. Therefore, it is wise to consider alternative energy to support their networking and telecommunication system.

As early as 1996, various technologies have been adapted by RMP, such as Malaysia Automated Fingerprint Identification System (MAFIS), Electronic Monitoring Device (EMD), Unmanned Aerial Vehicle (UAV), Analytic CCTV system and Voice Biometric Identification System (RMP, 2014). On the 27 December 2012, RMP has launched the "Go Green PDRM" campaign to raise awareness among the police officers on the importance of green practice and the green technology application in offices, police stations and others police institutes around the state (RMP, 2014). The initiative taken has make RMP as the leader and the among the first government agencies that has implemented the green practices and application in the government sector. In 2014, the "Blueprint of Green Practices and Green Application" has been established and launched, indicating the serious effort by the RMP in implementing the green energy practices in policing environment ((KeTTHA), 2014). The blueprint has outlined the framework, the strategies and the application of green technology for RMP which shall cover the products, equipment's and systems that protect the environment and minimize the negative impact from human activities. The Renewable Energy (RE) such as solar, wind and others are among the green energy that encourages being use.

In the RMP actual task, power shortage or interrupted electricity supply for Information Communication Technology
(ICT) and telecommunication facilities will be considered as a massive catastrophe especially during any crisis. Therefore, it is significant to have an alternative power supplies in the event of emergencies. This is necessary, especially considering the fact that the resources for generating conventional electricity (oil, gas and coal) is currently depleting (Hashim, 2010). Based on the valuable and important aforementioned study, it is vital for RMP for looking into alternative options for generating electricity during energy crisis. A police organization like Royal Malaysian Police (RMP) may have to face a risk of power interruptions that can harm the overall safety operations. Therefore to uphold the readiness level and sustainability purpose in the future, the Royal Malaysian Police (RMP) need to re-look over the alternative energy supply. Taking advantages with the blueprint released by RMP and considering the fact that Malaysia has substantial resources of solar energy, it is good step to synchronizing energy security issues with looking to solar energy as an alternative energy.

This paper will investigate the feasibility of solar energy through photovoltaic application in providing the green electricity to support the sustainability operation of RMP in the future. This study will provide an open solution on helping RMP to be more autonomous in generating own electricity.

\section{The Methodology}

The research begins with the desktop study by gathering the in-depth information through extensive literature review on the issues of energy security and its correlation with the renewable energy (RE), specifically on solar energy. The data of the daily power consumption $(\mathrm{Kw} / \mathrm{h})$ of RMP has been monitored and collected in order to evaluate the average of power consumption needed to be supplied by the solar PV systems. The research begins with the desktop study by 
gathering the in-depth information through extensive literature review on the issues of with the renewable energy (RE), specifically on solar energy. The data of the daily power consumption $(\mathrm{Kw} / \mathrm{h})$ of RMP has been monitored and collected in order to evaluate the average of power consumption needed to be supplied by the solar PV systems. The research extended to the simulation and modeling approaches by using prediction tools, known as Homer v2.8 (Severson \& St.Leger, 2013). These prediction tools will process the data accordingly to the input data and variables before come out with the results.

For the pilot project, this study has chosen the Network Operation Centre (NOC) building. This center acts as the central networking manager for RMP operation and comprises with high tech ICT facilities. This building is operated within the 24 hours-basis throughout the year and continuous electricity supply is an obligatory. Power shortage may interrupt the whole RMP's operation thus leading a potential risk on country's safety and security environment. As shown in Figure 6, the $6^{\text {th }}$ story of RMP building was selected. NOC is located on level three. Currently the energy backup for this building is derived from the $376 \mathrm{KVA}$ diesel generator, which projected to deliver $360 \mathrm{KW}$ of power in supporting various ICT facilities in the building. The generator only operated in auto switch mode during the occurrence of power shortage. Most of the time, this building relied on the electricity supplies from TNB. Therefore, it is essential to consider electricity generated from PV panels as an alternative option. The research methodology started by looking at a load profile of the building as suggested by Anwari, Rashid, Hui, Yee and Wee (2011). A one year (2014) electricity bill was collected and analyzed. From the bill, it has been identified that, this building consumed high energy with an average of 89000 kwh per month as show by Figure 7 . Subsequently, the electricity bill is also higher averaging at RM 45,000 per month. The load profile of the building was compared with the energy security and its correlation

load profile energy of NOC. The comparison was important in order to verify that the NOC used more energy than the other building's level. The energy trend is also shown in Figure 8 and 9. From Figure 8, it has been observed that the peak time of NOC for day time was started from $0900 \mathrm{hrs}$ until $1200 \mathrm{hrs}$ and significantly drop after that until $1700 \mathrm{hrs}$. Meanwhile, Figure 9 has shown that at night, NOC has consumed almost $90 \%$ usage of energy in that building with daily energy at an average of $138 \mathrm{kwh}$. The solar radiation data for the NOC was provided by Malaysia Meteorology Department at $5.4 \mathrm{kwhm}^{-2}$ and that indicates that this location experiencing almost 5.4hours of peak sun hours (PSH) throughout the day.

The areas available for solar panel installation also need to be identified. Therefore the roof sizing was modeling and applied as shown in figure 9. The measurement of the roof sizing was referring to the actual plan of the building which provided by the Jabatan Kerja Raya Malaysia (JKR). The medium power $250 \mathrm{~W}$ solar panel was selected for this pilot project and the typical size of the solar shown in figure 10 . From figure 10, Zone A has been identified as the most available area to install solar panel as the highest number of solar panel calculated available for that area. The site visit has been arranged to survey the area of the building and zone A was most significant area in term of shading, height and cabling distance. The shading analysis as shown by Figure 11 also identified the zone A, experienced less shading especially at peak hours' time. This method was following method as suggested by Frank Jackson (2007). This ongoing pilot study later will conduct numerical analysis to calculate the total solar panel, inverter, battery needed to engage with the existing system. Furthermore the suitable system either standalone system (off grid), grid connected system or hybrid system will be determined 


\section{IBCC 2016}

through simulation using Homer Prediction tool.

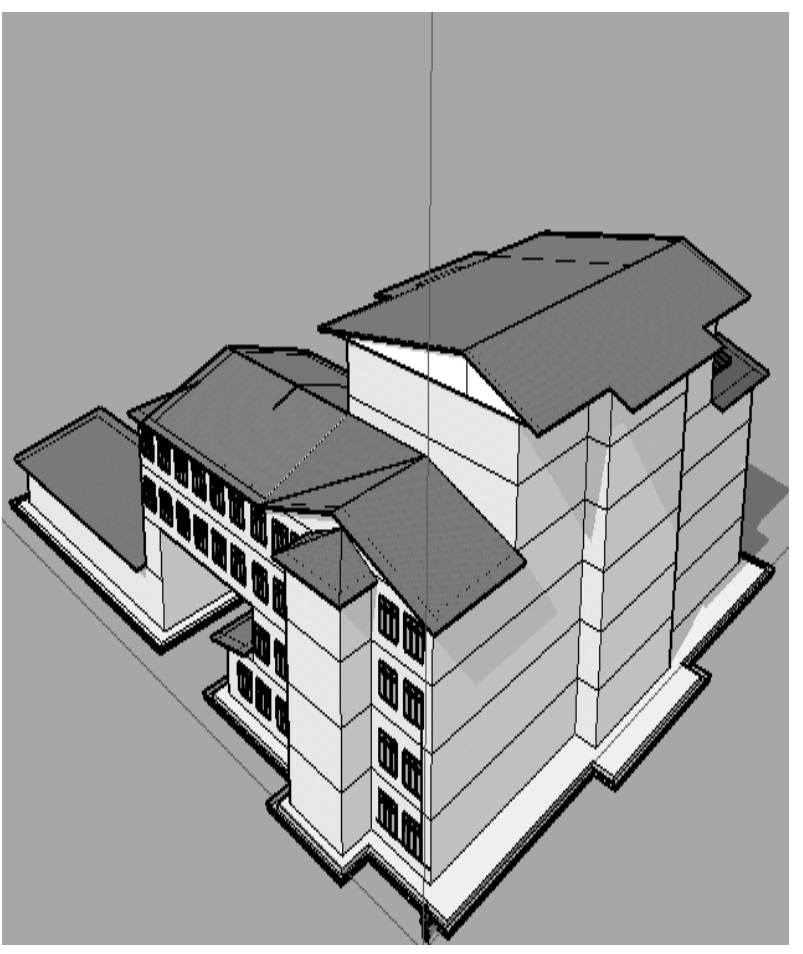

(a) Isometric view

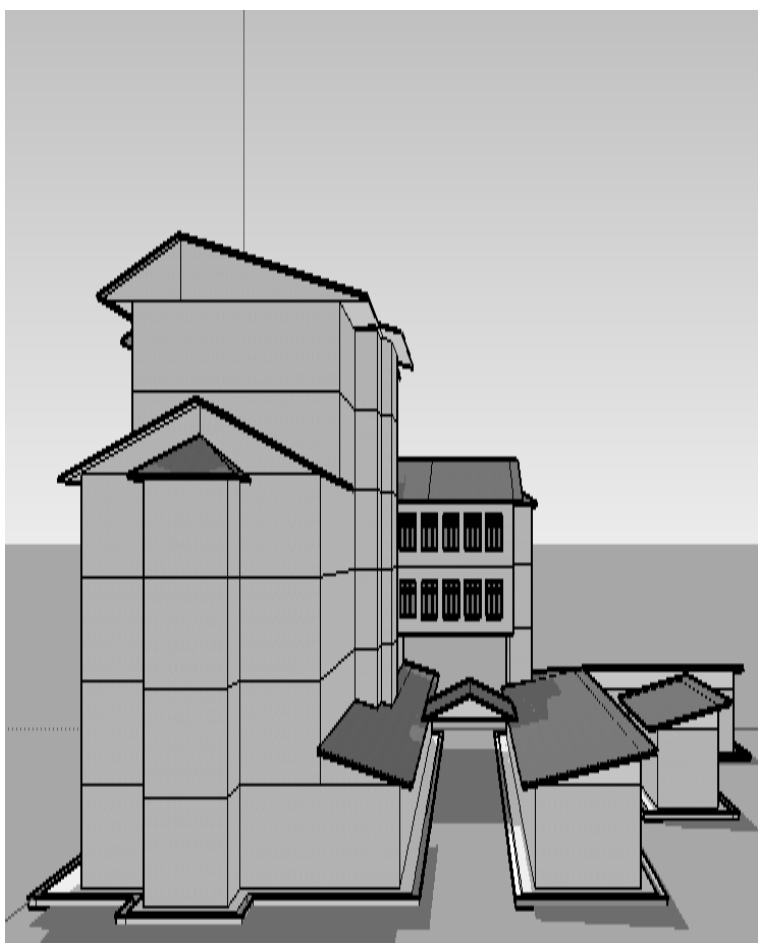

(b) Right view

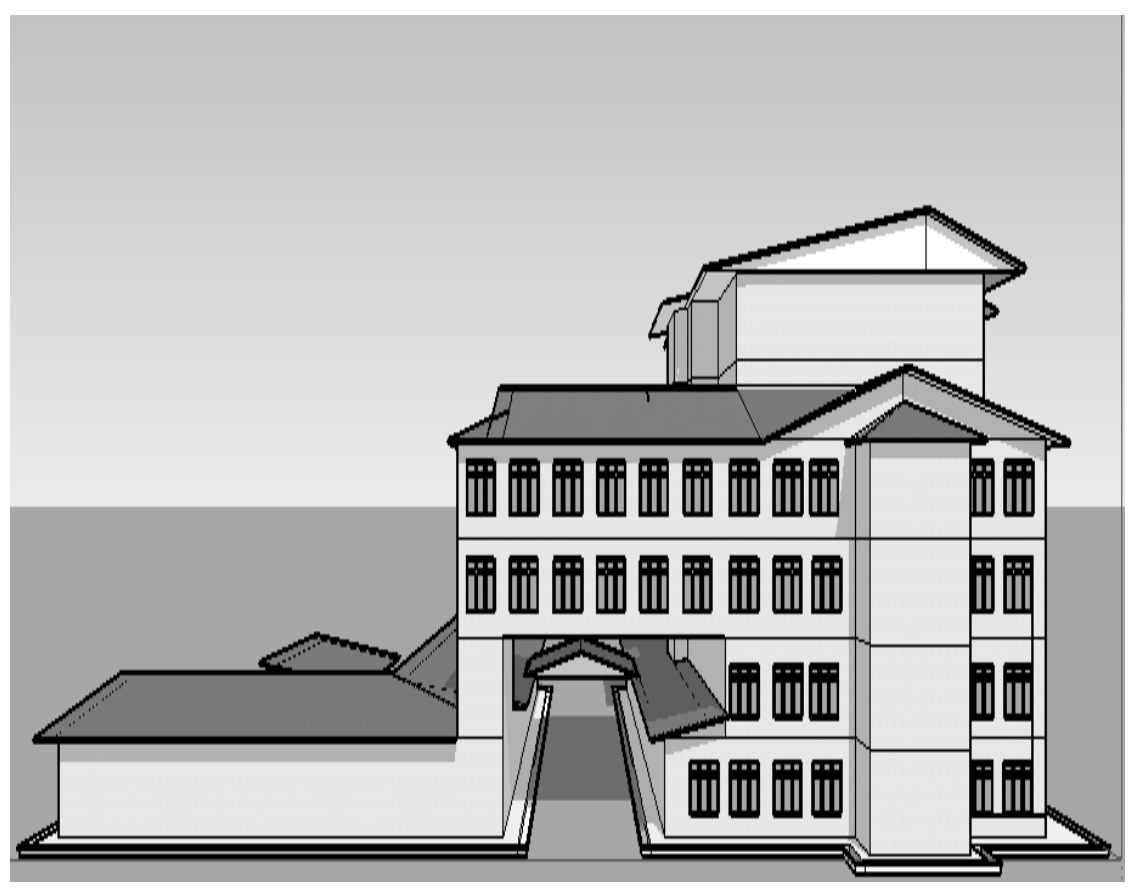

(c) Left view

Figure: 6(a), (b) and (c): RMP Building 


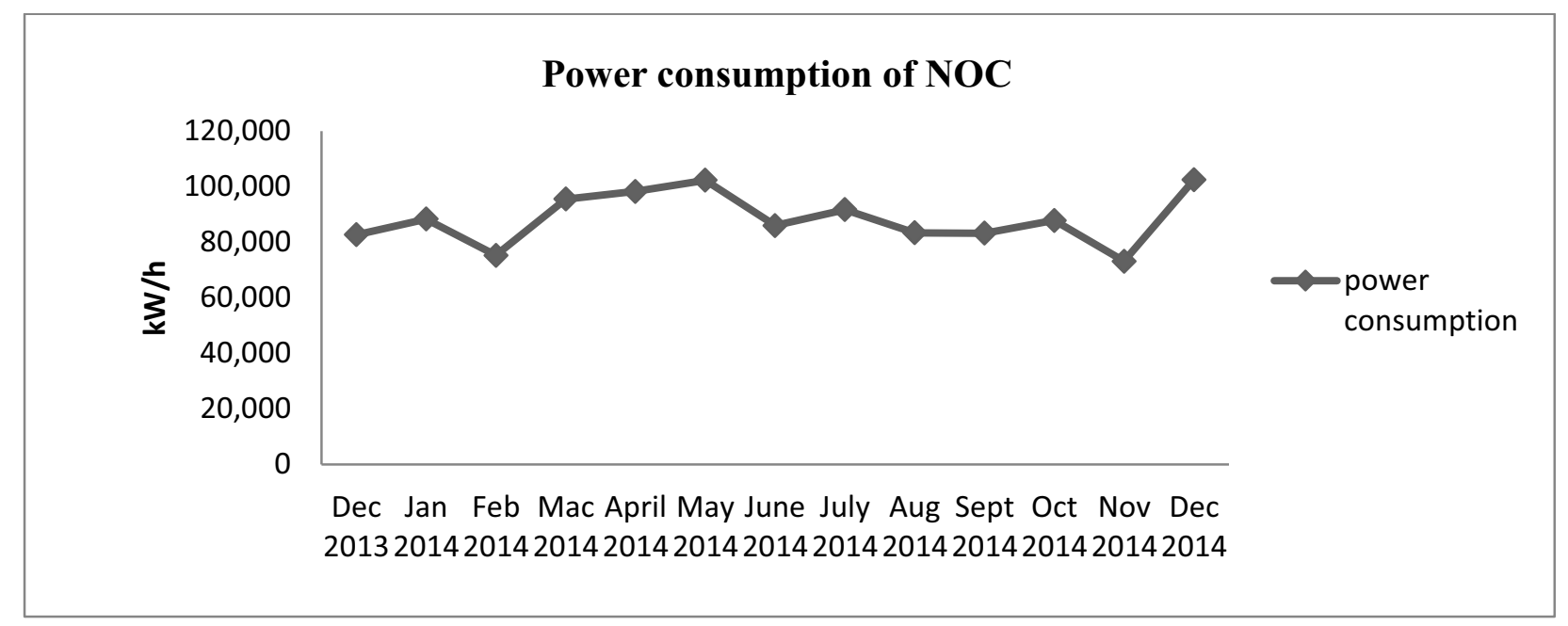

Figure 7: Network Operation Centre (NOC) power consumption (TNB, 2014).

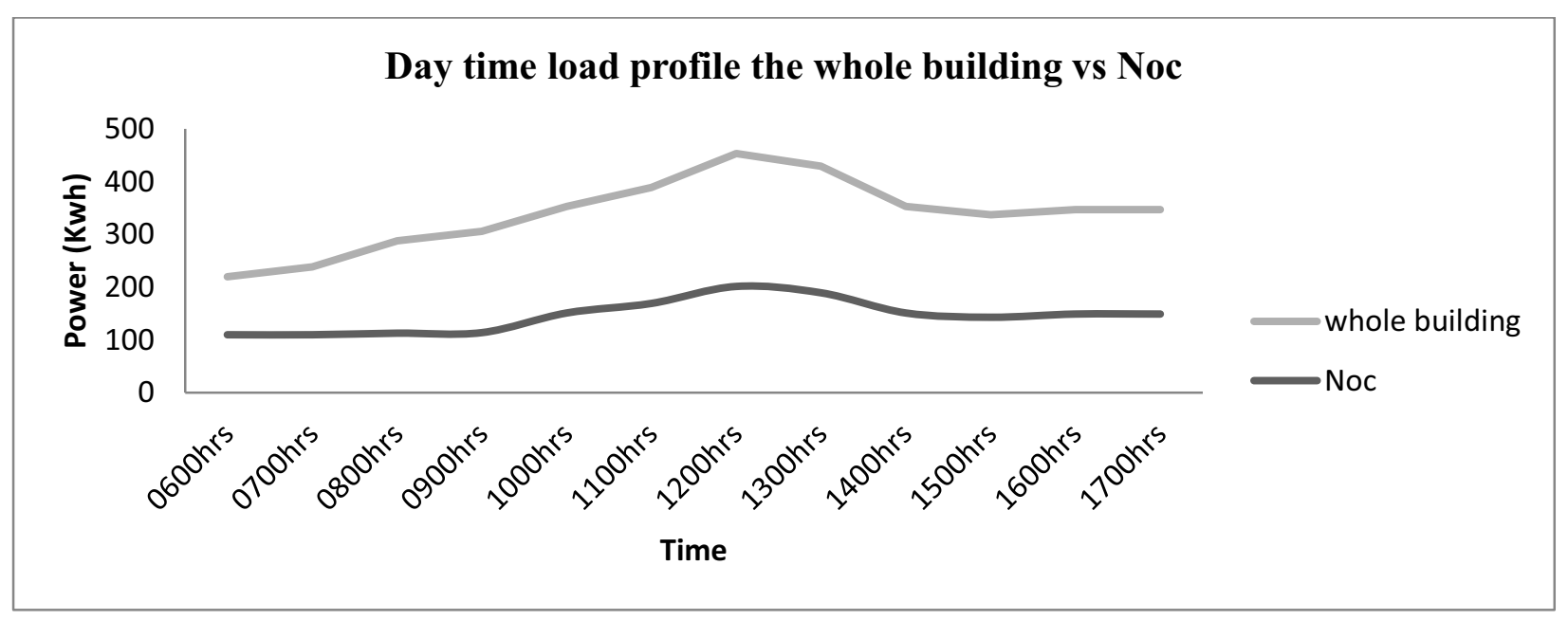

Figure 8: Network Operation Centre (NOC) power consumption

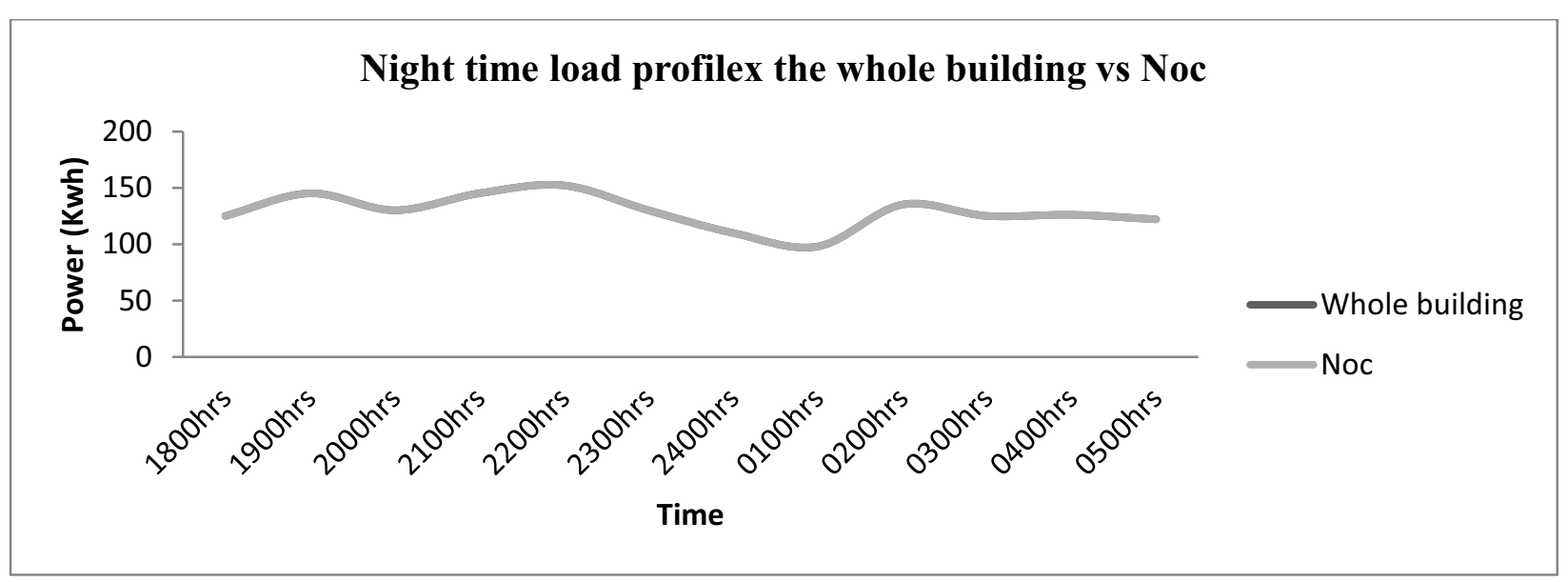

Figure 9: Network Operation Centre (NOC) power consumption 


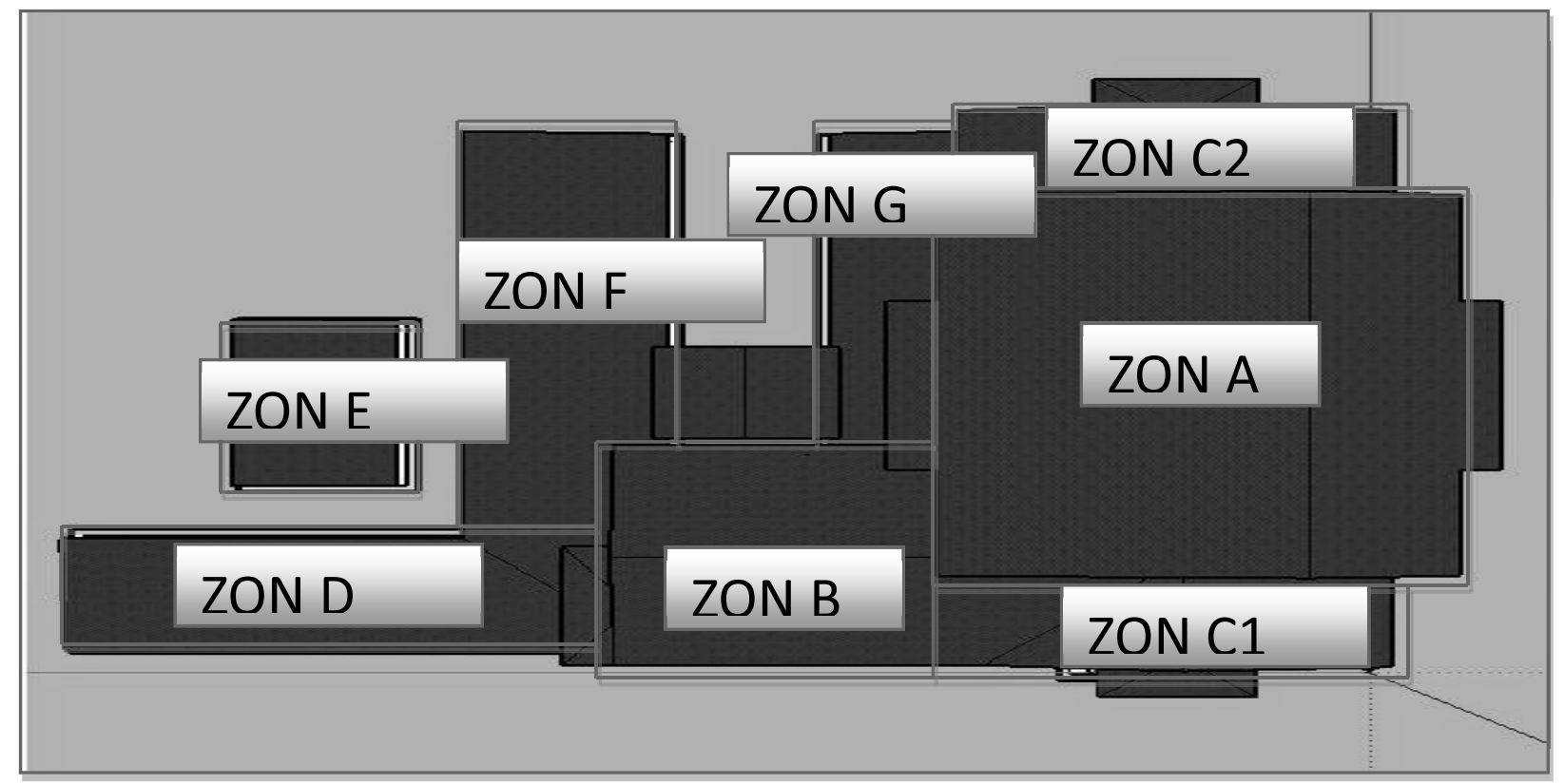

(a) Roof Zoning

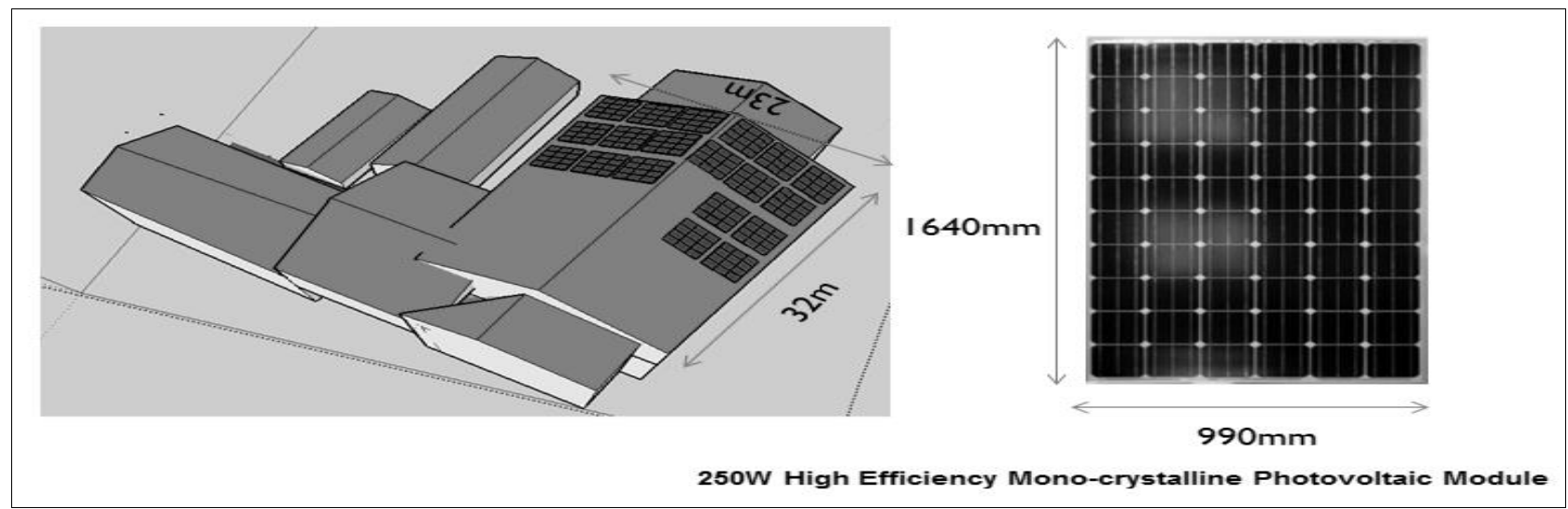

(b) Solar panel sizing

\begin{tabular}{|c|c|c|c|c|c|}
\hline No & Zone & Length $(\mathbf{m})$ & Width $(\mathbf{m})$ & Area $\left(\mathbf{m}^{2}\right)$ & $\begin{array}{c}\text { Solar PV capacity } \\
\text { (Area/ solar panel size) } \\
\left(\mathbf{m}^{2}\right)\end{array}$ \\
\hline I & A & 33 & 22 & 726 & 454 \\
\hline 2 & B & 21 & 15 & 315 & 325 \\
\hline 3 & C & 22 & 10 & 220 & 170 \\
\hline 4 & C2 & 21 & 10 & 210 & 72 \\
\hline 5 & D & 27 & 13 & 351 & 267 \\
\hline 6 & E & 16 & 8 & 128 & 111 \\
\hline 7 & F & 38 & 12 & 456 & 241 \\
\hline 8 & G & 32 & 7 & 224 & 140 \\
\hline
\end{tabular}

(c) Solar PV capacity

Figure 10 (a), (b) and (c): Roof sizing 


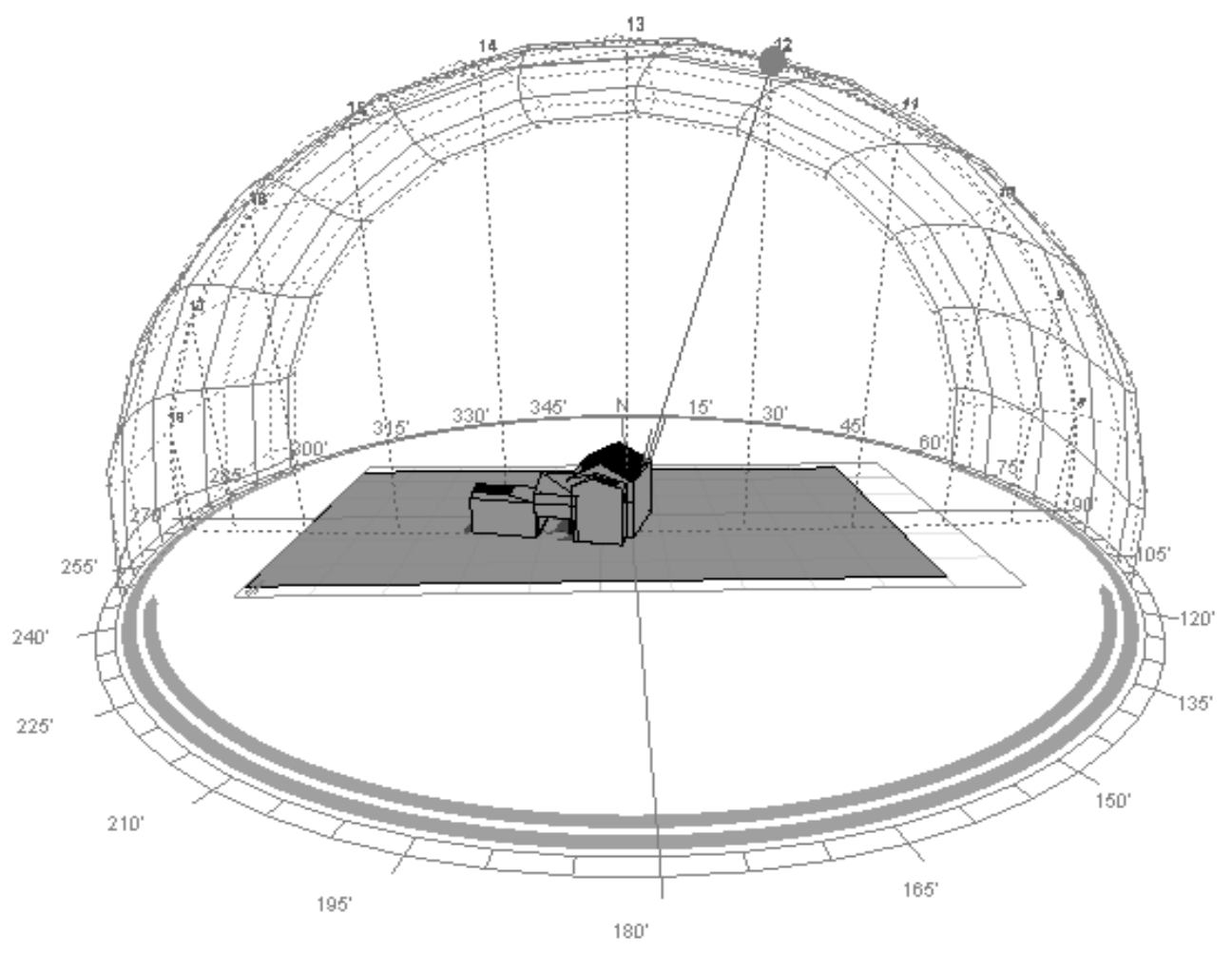

Figure 11: Shading analysis using Ecotect Analysis software

\section{The Result}

From the pilot study, it is observed that the cost of solar panel and others equipment would increase as well as capacity and efficiency increase. The cost estimation indicates in Table 3. The $250 \mathrm{~W}$ Polycrystalline solar panel has been choose for this pilot project considering the moderate efficiency and price per unit. For the storage system, Deep Cycle battery preferred as low maintenance required due to free maintenance capability. Meanwhile the Pure Sine Inverter is selected to convert DC supply to AC supply.The total cost estimation was design in flexible manner according to percentage of system coverage.

The minimum cost started from RM 34,113 and maximum cost estimated as RM 341,143.00. The existing high capacity diesel generator will generate AC power during power blackout. It is unfavorable if the generator was not integrated with the proposed system. Therefore there is a need to look for the practical system for NOC operation. The Homer Software has been used to predict the several system performances. The simulation result as shown in Table 4. It was observed that Hybrid system indicate the lowest Net Present Cost (NPC) compared with others system. The NPC value represent the life cycle cost of the system (Kamali \& Mekhilef, 2009). Kamali and Mekhilef (2009) state that smaller value of NPC for better system. Meanwhile the system which solely rely on generator record highest NPC followed by grid only system. Instead of that, hybrid system record lowest reading for the others criteria. Therefore hybrid system much preferred for this pilot project.

\section{Respective Outcome}

This research at the firsthand will provide the RMP on the information of fundamental issues about energy security in Malaysia and significance impact or risk that RMP may face in the future. This research also will provide the information on the prospective of Solar PV systems to support sustainability of RMP especially during energy crisis. Furthermore, this research will support the effort made by RMP to encourage the intensive use of Green Technology as mentioned in the blue print policy released by RMP. This is significance with the solar energy purpose in the research.

This research could be used as a guidance and reference for RMP in the process of acquiring suitable solar PV technology from many type of Solar PV system offered in the commercial market. A proper justification will be made base on the research output and not totally depended on the supplier information; this includes quotation and catalogues. It is hoped that in the future there will be standard framework that could be adopted for the new building design and construction. This wills covers methodology applies through the modeling; simulation and economic analysis include detailed specification on preparation and evaluation. Instead of considering the energy security issues and the green electricity prospective, the solar PV system must able to achieve the "value for money" purposes, with comprises affordable price with the good quality and standard operation. 


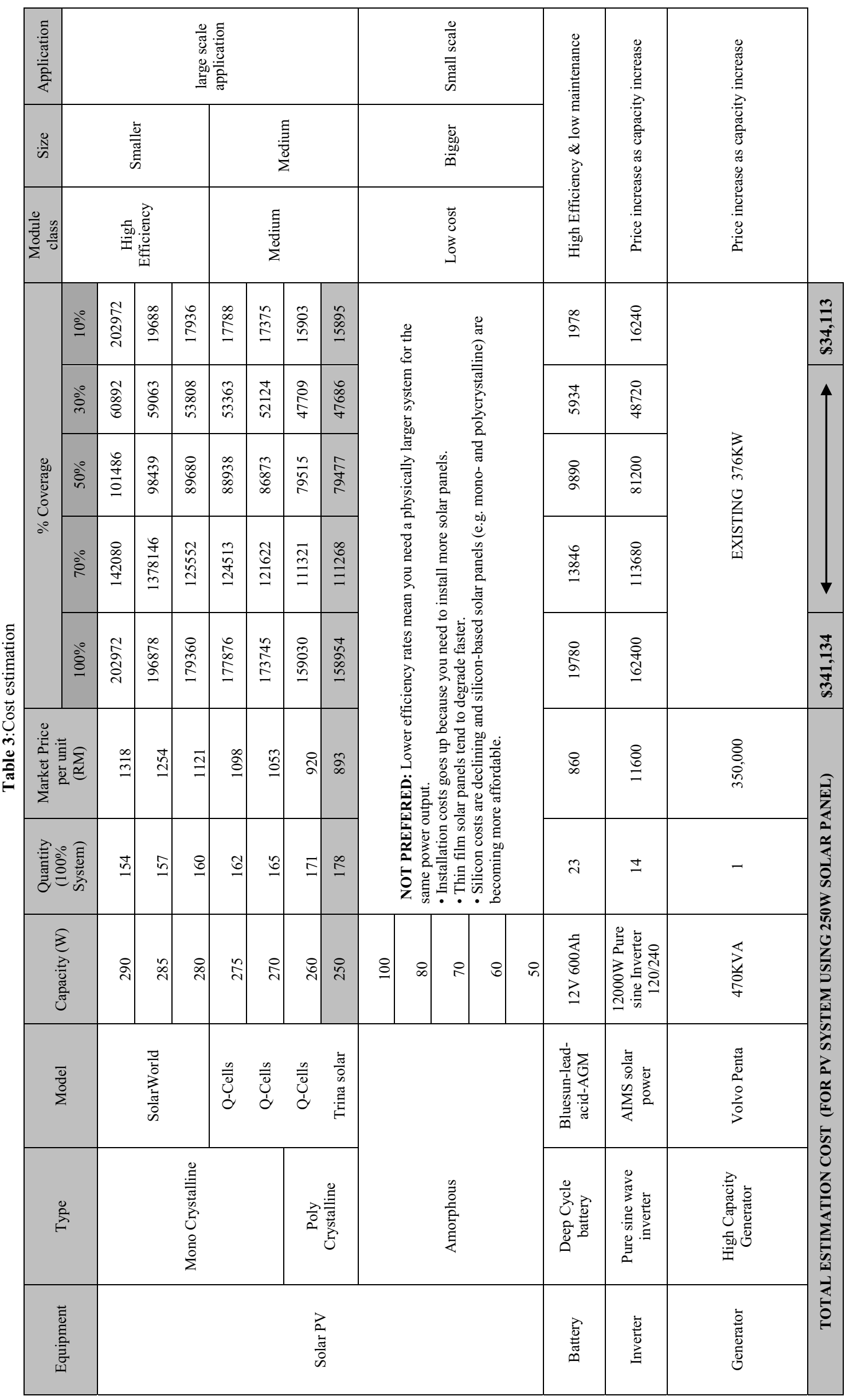


Table 4: System Comparison

\begin{tabular}{|c|c|c|c|c|c|c|c|c|}
\hline No & $\begin{array}{l}\text { System } \\
\text { Type }\end{array}$ & $\begin{array}{l}\text { Net Present } \\
\text { Cost (\$US) }\end{array}$ & $\begin{array}{c}\text { Cost } \\
\text { Operating }\end{array}$ & $\begin{array}{l}\text { Cost Of } \\
\text { Energy } \\
\text { (COE) } \\
\text { (\$US) }\end{array}$ & $\begin{array}{c}\text { Grid } \\
\text { Purchase } \\
\text { (kwh/yr) }\end{array}$ & $\begin{array}{c}\text { Generator } \\
\text { Production } \\
\text { (kwh/yr) }\end{array}$ & $\begin{array}{l}\text { Photovoltaic } \\
\text { (PV) } \\
\text { Production } \\
\text { (kwh/yr) }\end{array}$ & $\begin{array}{c}\text { Emission } \\
(\mathrm{kg} / \mathrm{yr})\end{array}$ \\
\hline 1. & Grid Only & $\$ 3,155,475$ & $\$ 246,842$ & $\$ 0.22$ & $1,122,011$ & - & - & 709,111 \\
\hline 2. & $\begin{array}{l}\text { Grid + } \\
\text { Generator } \\
\text { (Generator } \\
\text { fully used) }\end{array}$ & $\$ 6,719,763$ & $\$ 532,619$ & $\$-0.122$ & 0 & - & - & 890,651 \\
\hline 3 & $\begin{array}{c}\text { Grid + } \\
\text { Generator } \\
\text { (Generator } \\
\text { schedule) }\end{array}$ & $\$ 1,909,678$ & $\$ 142,413$ & $\$ 0.09$ & $1,033,772$ & 547.500 & - & 735,062 \\
\hline 4 & $\begin{array}{l}\text { Grid + } \\
\text { Generator } \\
\text { schedule + } \\
\text { Solar PV } \\
\text { system } \\
\text { (Hybrid } \\
\text { system) }\end{array}$ & $\$ 2,245,360$ & $\$ 163,656$ & $\$ 0.12$ & 998,972 & 411,720 & 71,300 & 700,343 \\
\hline 5 & $\begin{array}{c}\text { Grid + } \\
\text { Generator } \\
\text { schedule + } \\
\text { Solar PV } \\
\text { system+ } \\
\text { Battery } \\
\text { (Hybrid } \\
\text { system) }\end{array}$ & $\$ 2,120,392$ & $\$ 156,573$ & $\$ 0.11$ & 965,500 & 411,720 & 71,701 & 685,508 \\
\hline
\end{tabular}

\section{References}

1. (KeTTHA). (2014). Launch Of PDRM Blueprint On Geen Practices and Green Technology Applications. Retrieved from www.greentechmalaysia.my/file/media/MGTC PDRM Blueprint.pdf

2. Ahmad, N. A. (2011). Towards Sustaninable in Malaysia: IN the Perspective of Energy Security for Buildings. Procedia Engineering, 20, 222-229.3

3. Ali, R., Daut, I., \& Taib, S. (2012). A review on exixting and future energy sources for electrical power generation in malaysia. Reneawable and Sustainable Energy Reveiewa, 16(2012), 40474055.

4. Amin, N., Lung, C. W., \& Sopian, K. (2009). A practical field study of various solar cells on their performance in Malaysia. Renewable Energy, $34(8)$, 1939-1946.

http://doi.org/10.1016/j.renene.2008.12.005

5. Ang, B. W., Choong, W. L., \& Ng, T. S. (2015). security: Definitions, dimensions and indexes. Renewable and Sustainable Energy Reviews, 42, -1093. http://doi.org/10.1016/j.rser.2014.10.064

6. Anwari, M., Rashid, M. I. M., Hui, H. I., Yee, T. W., \& Wee, C. K. (2011). Photovoltaic power system simulation for small industry area. International Conference on Electrical, Control and Computer Engineering 2011 (InECCE), 263268. http://doi.org/10.1109/INECCE.2011.5953

7. Chua, S. C., \& Oh, T. H. (2011). Solar Energy Outlook in Malaysia. Renewable and Sustainable Energy Reviews, 16(2012), 564-574.

8. Davidson, D. (2015). swk blackout2. Retrieved January 5, 2016, from http://www.themalaysianinsider.com/malaysia/arti cle/power-back-after-massive-sarawak-blackout

9. 9. F.M Sukki R.R Inigueza, S.H. Abu-Bakar, A. B. M., \& S.H. Mohd Yasin B.G. Stewart, S. M. M. (2012). Solar photovoltaic in Malaysia:The way forward. Renewable and Sustainable Energy Reviews, 16(2012), 5232-5244

10. 10. Frank Jackson. (2007). Planning and 
Installing solar PV system. Infor (2nd editio). Earthscan

11. Hashim, S. M. (2010). A Malaysian National Prerogative: Engaging West Asia for Long Term Energy deals and Co-operation. International Journal of West Asian Studies, 2(No 1), 19-35. http://doi.org/10.5895/ijwas.2010.02

12. Hasimah, A. R., \& M.N.Khalid. (2009). Assessment of PV Cell Performance Under ActualMalaysia Operating Condition. Power Engineering Confrence. Australia.

13. Hobman, E. V., \& Frederiks, E. R. (2014). Barriers to green electricity subscription in Australia: "Love the environment, love renewable energy but why should I pay more?" Energy Research \& Social Science, $3, \quad 78-88$. http://doi.org/10.1016/j.erss.2014.07.009

14. Ismail, A. M., Ramirez-Iniguez, R., Asif, M., Munir, A. B., \& Sukki, F. M. (2014). Progress of solar photovoltaic in ASEAN countries: A review. Renewable and Sustainable Energy Reviews, 48(2015), 399-412.

15. Johari, a., Hafshar, S. S., Ramli, M., \& Hashim, H. (2011). Potential use of solar photovoltaic in Peninsular Malaysia. 2011 IEEE Conference on Clean Energy and Technology (CET), 2, 110-114. http://doi.org/10.1109/CET.2011.6041446

16. Kadir, M. Z. A. A., Rafeeu, Y., \& Adam, N. M. (2010). Prospective scenarios for the full solar energy development in Malaysia. Renewable and Sustainable Energy Reviews, 14(2010), 30233031.

17. Kamali, S. K., \& Mekhilef, S. (2009). Evaluation study on grid connedted PV system at Universiti Malaya. Technical postgraduates(TECHPOS), International Conference. Kuala Lumpur: IEEE. http://doi.org/10.1109/TECHPOS.2009.5412043

18. Mering, R. (2015). swk blackout. Retrieved January 5, 2016, from http://www.thestar.com.my/news/nation/2013/06/2 8/sarawak-endures-worst-ever-blackout/

19. Muhammad-Sukki, F., Ramirez-Iniguez, R., AbuBakar, S. H., McMeekin, S. G., \& Stewart, B. G. (2011). An evaluation of the installation of solar photovoltaic in residential houses in Malaysia: Past, present, and future. Energy Policy, 39(12), 7975-7987.

http://doi.org/10.1016/j.enpol.2011.09.052

20. Oh, T. H., Lalchand, G., \& Chua, S. C. (2014). Juggling act of electricity demand and supply in Peninsular Malaysia: Energy efficiency, renewable energy or nuclear? Renewable and Sustainable Energy Reviews, 37, 809-821. http://doi.org/10.1016/j.rser.2014.05.070

21. Othman, J., \& Jafari, Y. (2012). Accounting for Depletion of Oil and Gas Resources in Malaysia. Natural Resources Research, 21(4), 483-494. http://doi.org/10.1007/s11053-012-9192-2

22. RMP. (2014). Kepolisan Berteknologi Tinggi.
Retrieved November 22, 2015, from http://www.bharian.com.my/

23. Selvakkumaran, S., \& Limmeechokchai, B. (2013). Energy security and co-benefits of energy efficiency improvement in three Asian countries. Renewable and Sustainable Energy Reviews, 20, 491-503. http://doi.org/10.1016/j.rser.2012.12.004

24. Severson, B., \& St.Leger, A. (2013). Feasibility Study of Photovoltaic Panels inMilitary Temporary Housing Structures. Green Technologies Conference, 2013 IEEE. Denver,CO.

25. 25. TNB. 2013-2014 NOC electricity bill (2014). Jn Semarak. Kuala Lumpur 